Sains Malaysiana 50(8)(2021): 2193-2205

http://doi.org/10.17576/jsm-2021-5008-05

\title{
Phenolic Content and Biological Activities of Ethanol Extracts from Medicinal Plants in East Kalimantan, Indonesia
}

(Kandungan Fenol dan Aktiviti Biologi Ekstrak Etanol daripada Tumbuhan Ubatan di Kalimantan Timur, Indonesia)

\author{
FRANXISCA MARIANI, RACHANEEKORN TAMMACHOTE, IRAWAN WIJAYA KUSUMA, WARINTHORN CHAVASIRI, \\ Hunsa PunNaPAYAK \& SeHANAT PRASONGSUK*
}

\section{ABSTRACT}

The Dayak tribe are the indigenous people of West Kutai, East Kalimantan, Indonesia, and they have experiences in using plants for traditional medicine and the commonly used plants include Baccaurea macrocarpa (Miq.) Müll.Arg., Entada phaseoloides (L.) Merr., Goniothalamus macrophyllus (Blume) Hook.f. \& Thomson, Gynura crepidioides Benth., Helicia robusta (Roxb.) R. Br var. robusta, Litsea elliptica, Pogostemon cablin (Blanco) Benth, and Rhodomyrtus tomentosa (Aiton) Hassk. Therefore, the present study aimed to analyze these plant species for their phenolic content, and antioxidant, antibacterial, anti-tyrosinase, and anticancer activities. The total phenolic content and total antioxidant capacity were analyzed using Folin-Ciocalteu reagent and the phosphomolybdenum method, respectively. The antioxidant activities were evaluated by DPPH and ABTS assays. The antibacterial activity was determined by agar well diffusion and microdilution methods against six bacterial strains. The anticancer activity of the plant extracts was assayed against MDA-MB-231 human breast cancer cells. Based on the ethanol extraction, the highest yield was obtained from L. elliptica $(10.42 \%)$, while $\mathrm{H}$. robusta extract contained the highest phenolic content, antioxidant capacity, and antioxidant activities. All the extracts exhibited antibacterial activities against all the tested strains of bacteria, with the highest activity found in R. tomentosa extract, which also showed the highest activity against the cancer cells. The ethanol extract from $\mathrm{E}$. phaseoloides exhibited tyrosinase inhibition activity $\left(I C_{50}=543.83 \pm 51.06 \mu \mathrm{g} / \mathrm{mL}\right)$. The results herein suggested that the ethanol extracts from some medicinal plants from East Kalimantan have potential as antioxidant, antibacterial, anticancer, and anti-tyrosinase agents.

Keywords: Antibacterial; anticancer; antioxidant; anti-tyrosinase; medicinal plant extract

\section{ABSTRAK}

Suku Dayak adalah penduduk pribumi Kutai Barat, Kalimantan Timur, Indonesia dan mereka berpengalaman menggunakan tumbuhan untuk perubatan tradisi. Tumbuhan yang umumnya digunakan oleh suku ini antaranya ialah Baccaurea macrocarpa (Miq.) Müll.Arg., Entada phaseoloides (L.) Merr., Goniothalamus macrophyllus (Blume) Hook.f. \& Thomson, Gynura crepidioides Benth., Helicia robusta (Roxb.) R. Br var. robusta, Litsea elliptica, Pogostemon cablin (Blanco) Benth, dan Rhodomyrtus tomentosa (Aiton) Hassk. Oleh itu, kajian ini bertujuan untuk menganalisis kandungan fenol dan aktiviti antioksidan, antibakteria, anti-tirosinase dan antikanser dalam spesies tumbuhan ini. Jumlah kandungan fenol dan jumlah kapasiti antioksidan dianalisis dengan menggunakan reagen Folin-Ciocalteu dan kaedah fosfomolibdenum. Aktiviti antioksidan menggunakan ujian DPPH dan ABTS manakala aktiviti antibakteria ditentukan dengan kaedah agar telaga sebaran dan mikro-pencairan terhadap enam strain bakteria. Aktiviti antikanser ekstrak tumbuhan telah diuji ke atas sel kanser payudara MDA-MB-231. Berdasarkan pengekstrakan etanol, hasil tertinggi diperoleh daripada L. elliptica (10.42\%), manakala ekstrak H. robusta mengandungi kandungan fenol, keupayaan antioksidan dan aktiviti antioksidan tertinggi. Semua ekstrak menunjukkan aktiviti antibakteria terhadap semua bakteria yang diuji, dengan aktiviti tertinggi terdapat dalam ekstrak R. tomentosa, yang juga menunjukkan aktiviti tertinggi terhadap sel kanser. Ekstrak etanol daripada E. phaseoloides pula memaparkan aktiviti perencatan tirosinase $\left(I C_{50}=543.83 \pm 51.06 \mu \mathrm{g} / \mathrm{mL}\right)$. Hasil kajian ini menunjukkan bahawa ekstrak etanol daripada beberapa tumbuhan ubatan dari Kalimantan Timur berpotensi sebagai agen antioksidan, antibakteria, antikanser dan anti-tirosinase.

Kata kunci: Antibakteria; antikanser; antioksidan; anti-tirosinase; ekstrak tumbuhan ubat 


\section{INTRODUCTION}

The indigenous people in Kalimantan Island belong to the Dayak tribes. They have long experiences in using herbal medicines from knowledge passed down through generations. The medicinal plants used by people in the Dayak Tunjung tribe in West Kutai, East Kalimantan, are boiled, smeared, pasted, and consumed either raw or steam. The Dayak Tunjung community in Linggang sub-district uses approximately 80 species of medicinal plants from 37 different families collected from the forest or cultivation (Runtunuwu 2013). Practically, many parts of the plants including Baccaurea lanceolate (miq.) M.A., Gynura procumbes (lour.) Merr and Litsea firma Hook. are utilized to treat several diseases, such as stomachache, headache, bone injury, fever, wound, acne, cancer, and diabetes (Diba et al. 2013). Yusro et al. (2014) reported that the leaf is the most commonly used part of the plant $(51.52 \%)$, followed by root, and fruit bark, while the stem is rarely used. The crushed leaves of Pogostemon cablin (Blanco) Benth are used to treat skin allergy, while a combination of Areca catechu and Piper betle is claimed to be able to cure herpes, and the raw shoots of Psidium guajava are consumed for diarrhea treatment (Runtunuwu 2013). B. macrocarpa is one of the most popular trees found in Dayak Benuaq and Tunjung traditional home gardens in Mencimai village as the tribespeople like to consume its sweet-tasting-fruits (Matius et al. 2018).

Medicinal plants have been reported to contain high phenolic contents, which comprise of a group of secondary metabolites that are produced through the shikimate pathway. Simple phenols, phenolic acids, coumarins, naphthoquinones, flavonoids, lignans, and tannins are classified under this group (Cheynier et al. 2013) that have antioxidant, bacterial growth inhibition, tyrosinase inhibition, and anticancer properties (Jdey et al. 2017; Muddathir et al. 2017; Sebaihi-Harzoun et al. 2018). Antioxidative compounds are associated with phenolics and function by hydrogen or electron donation to scavenge reactive oxygen species to become stable or inactive (Falleh et al. 2012). The study of antioxidants is important because they can also affect human health. The content of antioxidants in the human body should be in a balanced condition. Antioxidant deficiency can cause stress, leading to a higher production of reactive oxygen species (ROS), such as hydroxyl radicals, superoxide anion radicals, and hydrogen peroxide, than the enzymatic (e.g. glutathione peroxidase (GPx) and superoxide dismutase (SOD)) and non-enzymatic antioxidants (e.g. glutathione, ascorbic acid, and $\alpha$-tocopherol) (Krishnaiah et al. 2011). This can lead to many diseases, such as inflammation, cancer, and arthritis. Although antioxidants are normally produced in the human body, the production may be insufficient as a result of aging process or environmental and behavioral factors such as cigarette smoking, pollutants, and UV exposure (Pillai et al. 2005). The intake of food or supplements with a high content of antioxidants, such as from plant leaves, is needed to provide a healthy dietary source (Wilson et al. 2017). Phenolics function as antibacterial agents by damaging the structural, morphology, or function of the bacterial cell membrane (Wu et al. 2016). They also contain antityrosinase property, which is related to the structure of their natural substrates (tyrosine or monophenols and L-DOPA or $o$-diphenols) that enable such compounds to inhibit hydroxylation and/or oxidation processes in order to inhibit melanin production (Chang 2009). Although melanogenesis is a physiological process in human skin to protect it from UV radiation and photocarcinogenesis (Yamaguchi et al. 2006), hyperpigmentation can lead to skin problems, like melasma, freckles, and age spots (Patil et al. 2014). Accordingly, finding a new active ingredient(s) from plants that can control the tyrosinase activity and the synthesis of melanin is attractive for cosmetic or clinical applications.

For the reasons mentioned earlier, natural sources of antioxidant, antibacterial, anti-tyrosinase, and anticancer properties are important in medicinal plant research. Nevertheless, the scientific knowledge of indigenous plants from East Kalimantan (Indonesian Borneo) is still limited. Therefore, the present study aimed to evaluate the phenolic contents, and biological activities of ethanol extracts from the leaves of eight plant species used by the Dayak Benuaq tribe. The information gained from this study can be used to expand the utilization of these plants based on their activity(ies).

\section{Materials AND Methods}

\section{PLANT MATERIAL}

Fresh leaves of eight plant species with local names in parentheses: Baccaurea macrocarpa (Miq.) Müll. Arg. (Pasi Rosang), Entada phaseoloides (L.) Merr. (Beruruk), Goniothalamus macrophyllus (Blume) Hook.f. \& Thomson (Somputn Planuq), Gynura crepidioides Benth. (Kemudi Patah), Helicia robusta (Roxb.) R.Br var. robusta (Tidu), Litsea elliptica (Ayau Junuq), Pogostemon 
cablin (Blanco) Benth. (Nilam Koko), and Rhodomyrtus tomentosa (Aiton) Hassk. (Masisin Kubar) were collected by local people in the Temula Village, West Kutai, East Kalimantan, Indonesia in the rainy season (January to May). The plants were between 3-6 years old. Mature leaves with dark green or greenish color with no sign of destruction by insects or fungi were collected. The species were identified by morphological characteristics and the specimens were deposited in the Wood Chemistry Laboratory, Faculty of Forestry, Mulawarman University, East Kalimantan, Indonesia.

\section{SAMPLE PREPARATION}

The plant materials were air-dried under the shade for 3 days and then grounded into powder at room temperature. Powdered material $(10 \mathrm{~g})$ from each plant was extracted with $95 \%$ ethanol $(3 \times 100 \mathrm{~mL})$ for $48 \mathrm{~h}$ with constant shaking at $120 \mathrm{rpm}$, room temperature. The liquid extracts were then filtered through Whatman No. 1 filter paper (Sigma-Aldrich, MO, USA) and concentrated using a rotary evaporator at $40{ }^{\circ} \mathrm{C}$ to obtain ethanol crude extracts. Yields of extract (w/w) were calculated and then stored at $-20{ }^{\circ} \mathrm{C}$ until further use.

\section{DETERMINATION OF TOTAL PHENOLIC CONTENTS (TPC)}

The assay was performed according to Pientaweeratch et al. (2016). All extracts and gallic acid (Merck Chemical Co., Darmstadt, Germany) were dissolved in $1 \%(\mathrm{v} / \mathrm{v})$ dimethyl sulfoxide (DMSO) and distilled water. Twenty microliters of samples $(50 \mu \mathrm{g} / \mathrm{mL}$ of final concentration) or gallic acid solution $(0.195$ to 50 $\mu \mathrm{g} / \mathrm{mL}$ of final concentrations) were added into 96 -well plates (Corning ${ }^{\circledR}, \mathrm{NY}, \mathrm{USA}$ ) with $100 \mu \mathrm{L}$ of $10 \%$ (v/v) Folin-Ciocalteu reagent 2.0 N (Loba Chemie Pvt. Ltd., Mumbai, India). After $5 \mathrm{~min}, 80 \mu \mathrm{L}(75 \mathrm{mg} / \mathrm{mL})$ of sodium carbonate (BDH Chemicals, Toronto, Canada) was added to the mixture and incubated for $120 \mathrm{~min}$ in the dark at room temperature. All reactions were performed in triplicate. Measurement of the absorbance at $760 \mathrm{~nm}$ used SpectraMax M3 multi-mode microplate reader (Molecular Devices, Sunnyvale, CA, USA) with Softmax software (SoftMax, San Diego, CA, USA). One percent (v/v) DMSO in distilled water was used as a blank. A standard curve of gallic acid was made by linear regression to obtain the equation for samples calculation. TPC values were expressed as $\mathrm{mg}$ gallic acid equivalent $(\mathrm{GAE}) / \mathrm{g}$ of dried weight (DW) of extract.

\section{DETERMINATION OF TOTAL ANTIOXIDANT CAPACITY} (TAC)

The TAC was performed according to Prieto et al. (1999) with modification. Ascorbic acid $(5-100 \mu \mathrm{g} / \mathrm{mL})$ was used as a positive control. The final concentration of each plant sample was $50 \mu \mathrm{g} / \mathrm{mL}$. Forty microliters of sample solution were added to $400 \mu \mathrm{L}$ of TAC reagent solution (0.6 $\mathrm{M} \mathrm{H}_{2} \mathrm{SO}_{4}, 28 \mathrm{mM}$ sodium phosphate, and $4 \mathrm{mM}$ ammonium molybdate) then incubated at $95{ }^{\circ} \mathrm{C}$ for 90 min. After cooling to room temperature, $200 \mu \mathrm{L}$ of each tube was transferred into a 96 -well plate. All reactions were performed in triplicate. One percent (v/v) DMSO in distilled water was used as a blank. The absorbance was measured at $695 \mathrm{~nm}$. A standard curve of ascorbic acid was made by linear regression using Microsoft Excel ${ }^{\circledR}$. TAC unit was expressed as mg ascorbic acid equivalent (AAE) $/ \mathrm{g}$ of dried weight (DW) of extract.

\section{DPPH RADICAL SCAVENGING ASSAY}

The 2,2-diphenyl-1-picrylhydrazyl (DPPH) radical scavenging assay was modified from Lin et al. (2014). Fifty microliters of various concentrations $(0-1000 \mu \mathrm{g} /$ $\mathrm{mL}$ ) of the plant extracts dissolved in methanol containing $1 \%$ DMSO (v/v) were analyzed. Ascorbic acid was used as a positive control. The analyses were performed in triplicate. The reaction was observed by measuring absorbance at $512 \mathrm{~nm}$ using SpectraMax M3. An equation was used to measure the reduction percentage of DPPH free radical (Benmehdi et al. 2017):

$$
1-\frac{A_{\text {sample }}}{A_{\text {control }}} \times 100 \%
$$

where $\mathrm{A}_{\text {sample }}$ is the absorbance in the presence of the sample and $\mathrm{A}_{\text {control }}$ is the absorbance of the control (without sample). The $50 \%$ inhibition concentration $\left(\mathrm{IC}_{50}\right)$ of each sample then was calculated by using linear regression. Percent inhibition was calculated from $100 \mu \mathrm{g} / \mathrm{mL}$ of sample concentration.

\section{ABTS RADICAL SCAVENGING ASSAY}

The 2,2'-azino-bis(3-ethylbenzothiazoline-6-sulfonic acid) diammonium salt (ABTS) radical scavenging assay was performed based on Fu et al. (2014) with slight modification for dissolving of solution using distilled water. The absorbance was measured immediately or up to 3 min. $\mathrm{IC}_{50}$ was calculated using linear regression. 
Ascorbic acid was used as a positive control. Percent inhibition result was obtained from $100 \mu \mathrm{g} / \mathrm{mL}$ of the plant extracts. Distilled water was used as a negative control. Each sample was corrected with blank which contains the sample but without ABTS solution.

\section{ANTIBACTERIAL ASSAY}

The plant extracts were analyzed against various bacterial strains. Gram-negative bacteria included Pseudomonas aeruginosa TISTR 1287 and Salmonella typhi ATCC 422. Gram-positive bacteria included Propionibacterium acnes KCCM 41747, Staphylococcus aureus ATCC 25923, Streptococcus mutans ATCC 25175, and Streptococcus sobrinus KCCM 11898. Antibacterial assay was carried out using the agar-well diffusion method with $30 \mathrm{~mL}$ nutrient agar per plate (Yadav et al. 2015). Thirty microliters of samples and chloramphenicol as a positive control $(1,000 \mu \mathrm{g} / \mathrm{mL})$ were input into each well $(5$ $\mathrm{mm}$ of diameter). Inhibition values were calculated by comparing the zone of inhibition of samples ( $\mathrm{mm}$ ) with the zone of inhibition of positive control ( $\mathrm{mm}$ ) in percent. Minimum inhibitory concentration (MIC) was performed by the broth microdilution method (Sarker et al. 2007) with 12 concentrations by 2 -fold serial dilution $(0.49$ to $1000 \mu \mathrm{g} / \mathrm{mL}$ ) and bacterial suspension based on 0.5 McFarland standards in 96-well plate. One percent DMSO in the nutrient broth was used as a negative control. Each experiment was performed in triplicate.

\section{ANTI-TYROSINASE ACTIVITY}

This assay was performed according to Mapunya et al. (2012) with slight modification. Kojic acid (SigmaAldrich MO, USA) was used as a positive control. Onehundred microliters per well of L-tyrosine was used as the substrate to verify the monophenolase activity of mushroom tyrosinase. The absorbances were measured at $492 \mathrm{~nm}$ using SpectraMax M3 multi-mode microplate reader. The experiment was performed in triplicate.

\section{EVALUATION OF ANTICANCER ACTIVITY}

The assay was modified from the method described by Banerjee et al. (2016). MDA-MB-231 human breast cancer cell lines were cultured in high-glucose DMEM with $1 \%$ antibiotic-antimycotic (100×) and 10\% heat-inactivated fetal bovine serum at $37^{\circ} \mathrm{C}, 5 \% \mathrm{CO}_{2}$. All reagents were obtained from (Gibco, NY, USA). Ten thousand cells per well were seeded in 96-well-plates and incubated for $48 \mathrm{~h}$. $\mathrm{IC}_{50}$ was analyzed with varying final concentrations (15.625 to
$1000 \mu \mathrm{g} / \mathrm{mL}$ ) of extracts dissolved in media containing $1 \%$ DMSO. Each condition was performed in triplicate and incubated for $48 \mathrm{~h}$. Thereafter, the media was discarded and $90 \mu \mathrm{L}$ of fresh media with $10 \mu \mathrm{L}$ of PrestoBlue dying agent (Invitrogen, Carlsbad, CA, USA) was added, then incubated for $2 \mathrm{~h}$. Fluorescence units were measured at 570 as excitation and $600 \mathrm{~nm}$ as emission wavelength according to the manufacturer's recommendation.

\section{STATISTICAL ANALYSES}

Mean values and standard deviation (mean \pm SD) were determined from three replications. Statistical analyses of the data were performed with one-way analysis of variance (ANOVA) with significant differences $(\mathrm{p}<0.05)$ using Microsoft Excel ${ }^{\circledR}$ and IBM SPSS statistics 22 with Duncan's post hoc test. Correlations between TPC, TAC, DPPH, and ABTS were calculated by Pearson's coefficients and interpreted according to Mukaka (2012).

\section{RESULTS AND DISCUSSION}

\section{YIELD, TPC, TAC, DPPH, AND ABTS INHIBITIONS OF ETHANOL EXTRACTS}

In the present study, leaves of eight plant species that are well-known for their medicinal properties by the Dayak tribes were extracted with ethanol. The percentage of yields, TPC, TAC, DPPH, and ABTS inhibitions results are shown in Table 1.

L. elliptica gave the highest yield $(10.42 \% \mathrm{w} / \mathrm{w})$ while B. macrocarpa (Miq.) Müll.Arg. gave the lowest yield $(1.42 \%)$. The ethanol extract yields from other Litsea species from previous studies were relatively similar to those in this study (8.96 to $13.62 \%$ ) (Ahmmad et al. 2012; Pradeepa et al. 2011). However, the result from $R$. tomentosa leaves in this study was $5.68 \%$, which was different from the result (16.2\%) reported by Kusuma et al. (2016). The difference may be due to the different extraction duration, collection time (in June), and location (was collected nearby Samarinda city), even though the plants were collected from the same province in Indonesia.

For the TPC analysis, gallic acid was used as a positive control. The TPCs ranged from 61.79 to $576.04 \mathrm{mg}$ GAE/g DW. The highest TPC values were obtained from H. robusta (576.04 $\pm 0.025 \mathrm{mg} \mathrm{GAE} / \mathrm{g} \mathrm{DW})$ and followed by $R$. tomentosa $(307.50 \pm 28.49 \mathrm{mg} \mathrm{GAE} / \mathrm{g} \mathrm{DW})$, while the lowest value was obtained from $G$. crepidioides $(61.79$ $\pm 6.14 \mathrm{mg} \mathrm{GAE} / \mathrm{g} \mathrm{DW})$. 
Published information on $H$. robusta for its activities or compounds are very scarce. This is the first study on the phenolic content and antioxidant activity in the leaves of $H$. robusta. Lallawmawma (2016) reported flavonoids and tannins in a methanolic extract of its bark by phytochemical screening. The bark extract also contained two phenolic compounds: ferulic acid and gallic acid. Research about the phenolic content from stem bark extracts of other species from the same genus (Helicia nilagirica) showed $10.78 \mathrm{mg} \mathrm{GAE} / \mathrm{g}$ of ethanol extract (Zoremsiami 2017), which was relatively lower compared to the results obtained in this study.

The highest TAC value was obtained from $H$. robusta $(363.28 \pm 1.88 \mathrm{mg}$ AAE/g DW), while $R$. tomentosa gave a relatively high TAC $(218.37 \pm 14.34 \mathrm{mg} \mathrm{AAE} / \mathrm{g} \mathrm{DW})$. A correlation between the TPC and TAC was observed between the eight plants, as shown in Table 2 (Pearson's correlation coefficients $=0.835)$. The correlation between TPC and TAC showed a similar trend to a recent study by Lallawmawma (2016) that found three common antioxidants (gallic acid, ferulic acid, and lutein) in the bark of $H$. robusta. Gallic acid and ferulic acid are phenolic compounds, while lutein is a carotenoid derivative.

DPPH and ABTS assays were performed to investigate the antioxidant activities from all the leaf extracts. The results are presented as the percentage of inhibition and $\mathrm{IC}_{50}$ values. The percentage of inhibition of DPPH ranged from $25.27 \pm 0.45$ to $99.06 \pm 1.17$, whereas the $\mathrm{IC}_{50}$ values ranged from $6.86 \pm 0.29$ to 346.90 $\pm 22.34 \mu \mathrm{g} / \mathrm{mL}$. The percentage inhibition of ABTS ranged from $19.69 \pm 0.29$ to $98.13 \pm 0.55 \%$ and the $\mathrm{IC}_{50}$ values ranged from $35.93 \pm 0.04$ to $600.74 \pm 2.86 \mu \mathrm{g} / \mathrm{mL}$. $H$. robusta extract gave the highest antioxidant levels (with $\mathrm{IC}_{50}$ values of 6.86 and $35.93 \mu \mathrm{g} / \mathrm{mL}$ for DPPH and ABTS inhibition, respectively). The results from the DPPH and ABTS assays showed a positive correlation, as presented in Table 2 (Pearson's correlation coefficients $=0.970$ ) The correlations between DPPH and ABTS were caused by the hydroxyl groups of the compounds, which stabilize free radicals by donating hydrogen atoms (Krishnaiah et al. 2011).

There are limited studies regarding the bioactivities and compounds of $H$. robusta and none for its leaves extract information. The bark extract of $H$. robusta also showed a high radical scavenging activity according to the DPPH method ( $\mathrm{IC}_{50}$ of $49.4 \mu \mathrm{g} / \mathrm{mL}$ ) (Lallawmawma 2016). Nevertheless, to the best of our knowledge, the stem bark ethanol extract of another species $(H$. nilagirica $)$ had a lower inhibition according to its $\mathrm{IC}_{50}$ value (154.79 $\mu \mathrm{g} / \mathrm{mL}$ ) (Zoremsiami 2017), which was higher than that in the present study. $P$. cablin and $R$. tomentosa are candidates as antioxidants due to their activities at 100 $\mu \mathrm{g} / \mathrm{mL}$ when reacted with DPPH and ABTS solutions, respectively. G. crepidioides, which contained a low phenolic content, also has low antioxidant activity.

TABLE 1. Yield, TPC, TAC, DPPH, and ABTS inhibition activities of eight medicinal plants from East Kalimantan province, Indonesia

\begin{tabular}{|c|c|c|c|c|c|c|c|}
\hline \multirow{2}{*}{ Sample } & \multirow{2}{*}{$\begin{array}{c}\text { Yield } \\
(\%, w / w)^{*}\end{array}$} & \multirow{2}{*}{$\begin{array}{c}\text { TPC (mg } \\
\text { GAE/g DW) }\end{array}$} & \multirow{2}{*}{$\begin{array}{c}\mathrm{TAC}(\mathrm{mg} \\
\mathrm{AAE} / \mathrm{g} \mathrm{DW})\end{array}$} & \multicolumn{2}{|c|}{ DPPH } & \multicolumn{2}{|c|}{ ABTS } \\
\hline & & & & \%Inhibition & $\mathrm{IC}_{50}(\mu \mathrm{g} / \mathrm{mL})$ & \%Inhibition & $\mathrm{IC}_{50}(\mu \mathrm{g} / \mathrm{mL})$ \\
\hline ascorbic acid & & & & $96.60 \pm 1.05^{\mathrm{b}}$ & $12.72 \pm 0.23^{\mathrm{abc}}$ & $100.00 \pm 0.10^{\mathrm{a}}$ & $3.07 \pm 0.04^{\mathrm{a}}$ \\
\hline Baccaurea macrocarpa & 1.42 & $97.06 \pm 2.90^{\mathrm{d}}$ & $145.97 \pm 7.78^{c}$ & $25.27 \pm 0.45^{\mathrm{h}}$ & $143.51 \pm 8.13^{\mathrm{e}}$ & $29.78 \pm 0.32^{\mathrm{g}}$ & $380.28 \pm 10.94^{\mathrm{g}}$ \\
\hline Entada phaseoloides & 3.65 & $150.21 \pm 12.46^{\mathrm{c}}$ & $105.77 \pm 2.02^{\mathrm{d}}$ & $88.74 \pm 1.64^{\mathrm{e}}$ & $10.14 \pm 0.54^{\mathrm{ab}}$ & $64.51 \pm 2.87^{\mathrm{c}}$ & $71.00 \pm 4.80^{\mathrm{d}}$ \\
\hline $\begin{array}{l}\text { Goniothalamus } \\
\text { macrophyllus }\end{array}$ & 2.67 & $170.08 \pm 9.31^{\mathrm{c}}$ & $200.07 \pm 15.80^{\mathrm{b}}$ & $94.72 \pm 1.47^{\mathrm{bc}}$ & $23.33 \pm 1.15^{\mathrm{bcd}}$ & $54.22 \pm 1.64^{\mathrm{e}}$ & $89.73 \pm 4.82^{\mathrm{e}}$ \\
\hline Gynura crepidioides & 1.51 & $61.79 \pm 6.14^{\mathrm{e}}$ & $209.78 \pm 13.14^{b}$ & $33.09 \pm 0.05^{g}$ & $346.90 \pm 22.34^{\mathrm{f}}$ & $19.69 \pm 0.29^{\mathrm{h}}$ & $600.74 \pm 2.86^{\mathrm{h}}$ \\
\hline Helicia robusta & 4.73 & $576.04 \pm 9.15^{\mathrm{a}}$ & $363.28 \pm 1.88^{\mathrm{a}}$ & $93.10 \pm 0.53^{\mathrm{cd}}$ & $6.86 \pm 0.29^{\mathrm{a}}$ & $92.62 \pm 0.13^{b}$ & $35.93 \pm 0.29^{\mathrm{b}}$ \\
\hline Litsea elliptica & 10.42 & $115.10 \pm 6.71^{\mathrm{d}}$ & $91.61 \pm 5.84^{d}$ & $81.46 \pm 3.19^{\mathrm{f}}$ & $13.71 \pm 1.13^{\mathrm{abc}}$ & $60.83 \pm 4.39^{\mathrm{d}}$ & $84.69 \pm 4.20^{\mathrm{e}}$ \\
\hline Pogostemon cablin & 4.36 & $169.73 \pm 12.18^{c}$ & $167.48 \pm 6.27^{\mathrm{c}}$ & $99.06 \pm 1.17^{\mathrm{a}}$ & $36.30 \pm 1.26^{\mathrm{d}}$ & $42.28 \pm 0.48^{\mathrm{f}}$ & $139.43 \pm 1.42^{\mathrm{f}}$ \\
\hline $\begin{array}{l}\text { Rhodomyrtus } \\
\text { tomentosa }\end{array}$ & 5.68 & $307.50 \pm 28.49^{b}$ & $218.37 \pm 14.34^{b}$ & $91.11 \pm 0.39^{\mathrm{de}}$ & $27.11 \pm 1.16^{\mathrm{cd}}$ & $98.13 \pm 0.55^{\mathrm{a}}$ & $45.81 \pm 0.41^{\mathrm{c}}$ \\
\hline
\end{tabular}

* Yield was calculated by an equation: (weight of ethanol extract / weight of dried leaves) $\times 100 \%$. Percentage of inhibition (\%inhibition) of DPPH and ABTS were done at $100 \mu \mathrm{g} / \mathrm{mL}$. All results were mean $\pm \mathrm{SD}(n=3)$. Different letters in every column show significant difference $(P<0.05)$ 
TABLE 2. Pearson's correlation coefficients between TPC, TAC, DPPH, and ABTS

\begin{tabular}{ccccc}
\hline & TPC & TAC & DPPH & ABTS \\
\hline TPC & 1 & $0.835^{\mathrm{b}}$ & $-0.465^{\mathrm{d}}$ & $-0.550^{\mathrm{c}}$ \\
TAC & $0.835^{\mathrm{b}}$ & 1 & $0.016^{\mathrm{e}}$ & $-0.088^{\mathrm{e}}$ \\
DPPH & $-0.465^{\mathrm{d}}$ & $0.016^{\mathrm{e}}$ & 1 & $0.970^{\mathrm{a}}$ \\
ABTS & $-0.550^{\mathrm{c}}$ & $-0.088^{\mathrm{e}}$ & $0.970^{\mathrm{a}}$ & 1 \\
\hline
\end{tabular}

According to Mukaka (2012): ${ }^{\mathrm{a}} \pm 0.90-1.00$ (very high), ${ }^{\mathrm{b}} \pm 0.70-0.90$ (high), ${ }^{\mathrm{c}} \pm 0.50-0.70$ (moderate), ${ }^{\mathrm{d}} \pm 0.30-0.50$ (low),

${ }^{\mathrm{e}} \pm 0.00-0.30$ (negligible correlation)

\section{ANTIBACTERIAL ACTIVITIES}

The antibacterial activities of the extracts against 6 strains, including the percentage of inhibition, minimum inhibitory concentration (MIC), and minimum bactericidal concentration $(\mathrm{MBC})$ values are shown in Tables 3 and 4. All the plant extracts showed antibacterial activity against both Gram-negative and Gram-positive bacteria with an inhibition of $24 \%$ and above compared to inhibition zone of chloramphenicol. All the inhibition zone diameter of positive control against $S$. typhi, P. acnes, S. aureus, $S$. mutans, and $S$. sobrinus were susceptible (18.89 to $30.33 \mathrm{~mm}$ ), whereas for $P$. aeruginosa in intermediate $(13.67 \mathrm{~mm})$ criteria (detail in Supplementary Data 1). The inhibition of the extracts against Gramnegative bacteria (Table 3) included the inhibition of $P$. aeruginosa (48.8 - 73.9\%) and S. typhi (36 - 42\%). The inhibition of the extracts against Gram-positive bacteria included the inhibition of $P$. acnes, as shown in Table 4, in the range $24.1-33.9 \%$, S. aureus $(26.2-32.8 \%), S$. mutans (39.4 - 56.2\%), and S. sobrinus (29.7 - 41.9\%). Agar diffusion method is commonly used for qualitative and preliminary data due to the extract might not diffuse well in the agar media (Golus et al. 2016). Therefore, another methodology for antibacterial activity like broth microdilution was done for confirmation. $R$. tomentosa showed the highest antibacterial activities (based on MIC and $\mathrm{MBC}$ ) compared to the other extracts, which MIC and MBC values were at $1000 \mu \mathrm{g} / \mathrm{mL}$ or above. $R$. tomentosa showed the lowest MIC against $S$. sobrinus at $15.625 \mu \mathrm{g} /$ $\mathrm{mL}$, and P. acnes, S. typhi, and S. mutans at $31.25 \mu \mathrm{g} / \mathrm{mL}$. Higher concentrations of this extract were needed against S. aureus $(62.5 \mu \mathrm{g} / \mathrm{mL})$ and P. aeruginosa $(1000 \mu \mathrm{g} / \mathrm{mL})$. MBC values of $R$. tomentosa below $1000 \mu \mathrm{g} / \mathrm{mL}$ were shown against three bacterial strains, S. mutans at 125 $\mu \mathrm{g} / \mathrm{mL}, S$. aureus at $250 \mu \mathrm{g} / \mathrm{mL}$, and S. sobrinus at 500 $\mu \mathrm{g} / \mathrm{mL}$. Different result between agar-well diffusion and broth microdilution methods could be happened because of the ability of extracts to interfere directly to the bacteria (Hood et al. 2003).

Previous studies have reported information about the antioxidant and antibacterial activities of $R$. tomentosa. However, less information regarding ethanol extract from leaves has been reported and no information about TPC, TAC, ABTS, and antibacterial activity against $S$. sobrinus. Saising et al. (2011) reported the antibacterial activity of ethanol extract from R. tomentosa from Songkhla, Thailand, against $S$. aureus. The results showed lower MIC $(32 \mu \mathrm{g} / \mathrm{mL})$ and MBC $(64 \mu \mathrm{g} / \mathrm{mL})$ values compared to those in this study. Similarly, ethanol extract of $R$. tomentosa at a higher concentration $(100 \mu \mathrm{g} / \mathrm{well})$ also exhibited antibacterial activity effectively against $S$. typhi and P. acnes (Kusuma et al. 2016). Lower MIC $(3.9 \mu \mathrm{g} / \mathrm{mL})$ but the same MBC values were observed in leaf ethanol extract against $S$. mutans NPRCM 2010 (Limsuwan et al. 2009) compared to those in this study. Some compounds i.e., tomentosone $\mathrm{C}$-and rhodomyrtosone $\mathrm{C}$ that isolated from $R$. tomentosa leaves might contribute to the activity (Krisyanella et al. 2011; Liu et al. 2016). Our study suggested that $R$. tomentosa could be used for antibacterial purposes against both Gram-positive and Gram-negative bacteria. Gram-negative bacteria build by cell wall that having many layers, including a lipid outer membrane, which makes the antibacterial constituents impenetrable in order to lyse the cells. Therefore, extract with strong potential of antibacterial inhibition is needed (Beveridge 1999). 
TABLE 3. Antibacterial activities of ethanol extracts against Gram-negative bacteria

\begin{tabular}{|c|c|c|c|c|c|c|}
\hline \multirow{2}{*}{ Sample } & \multicolumn{3}{|c|}{ P. aeruginosa TISTR 1287} & \multicolumn{3}{|c|}{ S. typhi ATCC 422} \\
\hline & \%Inhibition & MIC & MBC & \%Inhibition & MIC & MBC \\
\hline Chloramphenicol & $100.0 \pm 0^{\mathrm{a}}$ & 62.5 & 250 & $100.0 \pm 0^{\mathrm{a}}$ & 15.625 & 31.25 \\
\hline B. macrocarpa & $73.9 \pm 6.8^{b}$ & 1000 & $>1000$ & $38.6 \pm 2.4^{\mathrm{bcd}}$ & 1000 & $>1000$ \\
\hline E. phaseoloides & $60.0 \pm 4.1^{\mathrm{cd}}$ & 1000 & $>1000$ & $41.0 \pm 1.0^{\mathrm{bc}}$ & 1000 & $>1000$ \\
\hline G. macrophyllus & $64.7 \pm 1.9^{\mathrm{bc}}$ & 1000 & $>1000$ & $40.5 \pm 3.2^{\mathrm{bc}}$ & 1000 & $>1000$ \\
\hline G. crepidioides & $57.8 \pm 4.9^{\mathrm{cd}}$ & 1000 & $>1000$ & $37.8 \pm 3.5^{\mathrm{bcd}}$ & 1000 & $>1000$ \\
\hline H. robusta & $57.4 \pm 1.6^{\mathrm{cd}}$ & 1000 & $>1000$ & $37.1 \pm 2.0^{\mathrm{cd}}$ & 1000 & $>1000$ \\
\hline L. elliptica & $48.8 \pm 0.1^{\mathrm{d}}$ & $>1000$ & $>1000$ & $42.0 \pm 3.2^{b}$ & $>1000$ & $>1000$ \\
\hline P. cablin & $55.1 \pm 3.9^{\mathrm{cd}}$ & 1000 & $>1000$ & $36.0 \pm 1.2^{\mathrm{d}}$ & $>1000$ & $>1000$ \\
\hline R. tomentosa & $53.8 \pm 2.6^{\mathrm{cd}}$ & 1000 & $>1000$ & $37.4 \pm 1.2^{\mathrm{cd}}$ & 31.25 & $>1000$ \\
\hline
\end{tabular}

\%inhibition was done at $1000 \mu \mathrm{g} / \mathrm{mL}$ and represented by mean $\pm \mathrm{SD}(\mathrm{n}=3)$. MIC and MBC units are $\mu \mathrm{g} / \mathrm{mL}$. Different letters in \%inhibition column shows significant difference $(P<0.05)$

TABLE 4. Antibacterial activities of ethanol extracts against Gram-positive bacteria

\begin{tabular}{|c|c|c|c|c|c|c|c|c|c|c|c|c|}
\hline \multirow{2}{*}{ Sample } & \multicolumn{3}{|c|}{ P. acnes KCCM 41747} & \multicolumn{3}{|c|}{ S. aureus ATCC 25923} & \multicolumn{3}{|c|}{ S. mutans ATCC 25175} & \multicolumn{3}{|c|}{ S. sobrinus KCCM 11898} \\
\hline & \%Inhibition & MIC & $\mathrm{MBC}$ & \%Inhibition & MIC & $\mathrm{MBC}$ & \%Inhibition & MIC & $\mathrm{MBC}$ & \%Inhibition & MIC & $\mathrm{MBC}$ \\
\hline Chloramphenicol & $100.0 \pm 0^{\mathrm{a}}$ & 3.90625 & 15.625 & $100.0 \pm 0^{\mathrm{a}}$ & 15.625 & 31.25 & $100.0 \pm 0^{\mathrm{a}}$ & 3.90625 & 7.8125 & $100.0 \pm 0^{\mathrm{a}}$ & 3.90625 & 3.90625 \\
\hline B. macrocarpa & $29 \pm 1.8^{c}$ & $>1000$ & $>1000$ & $28.1 \pm 0.8^{\text {ef }}$ & 1000 & $>1000$ & $47.1 \pm 2.0^{\mathrm{c}}$ & $>1000$ & $>1000$ & $35.1 \pm 1.8^{\mathrm{d}}$ & 1000 & $>1000$ \\
\hline E. phaseoloides & $24.1 \pm 1.9^{\mathrm{d}}$ & $>1000$ & $>1000$ & $31.4 \pm 1.1^{\mathrm{bc}}$ & $>1000$ & $>1000$ & $43.9 \pm 0.8^{\mathrm{d}}$ & 1000 & $>1000$ & $39.6 \pm 0.1^{\mathrm{bc}}$ & 1000 & $>1000$ \\
\hline G. macrophyllus & $27.9 \pm 2.7^{c}$ & $>1000$ & $>1000$ & $30.8 \pm 1.7^{\mathrm{bcd}}$ & 1000 & $>1000$ & $39.4 \pm 1.9^{\mathrm{e}}$ & 1000 & $>1000$ & $29.7 \pm 2.5^{\mathrm{f}}$ & $>1000$ & $>1000$ \\
\hline G. crepidioides & $33.9 \pm 0.9^{b}$ & $>1000$ & $>1000$ & $28.5 \pm 1.6^{\mathrm{def}}$ & 1000 & $>1000$ & $42.3 \pm 1.1^{\mathrm{de}}$ & 1000 & $>1000$ & $34.5 \pm 1.1^{\mathrm{d}}$ & 1000 & $>1000$ \\
\hline H. robusta & $28.6 \pm 2.2^{c}$ & $>1000$ & $>1000$ & $29.7 \pm 0.8^{\text {cde }}$ & 1000 & $>1000$ & $41.8 \pm 4.0^{\mathrm{de}}$ & $>1000$ & $>1000$ & $33.6 \pm 0.5^{\mathrm{de}}$ & 1000 & $>1000$ \\
\hline L. elliptica & $32.6 \pm 1.0^{\mathrm{b}}$ & $>1000$ & $>1000$ & $32.8 \pm 1.9^{\mathrm{b}}$ & 1000 & $>1000$ & $55.3 \pm 1.8^{\mathrm{b}}$ & 1000 & $>1000$ & $39.0 \pm 1.8^{c}$ & $>1000$ & $>1000$ \\
\hline P. cablin & $28.3 \pm 0.5^{\mathrm{c}}$ & $>1000$ & $>1000$ & $26.2 \pm 1.6^{\mathrm{f}}$ & $>1000$ & $>1000$ & $42.1 \pm 1.1^{\mathrm{de}}$ & $>1000$ & $>1000$ & $31.5 \pm 1.8^{\mathrm{ef}}$ & $>1000$ & $>1000$ \\
\hline R. tomentosa & $31.2 \pm 2.6^{\mathrm{bc}}$ & 31.25 & $>1000$ & $32.0 \pm 1.9^{\mathrm{bc}}$ & 62.5 & 250 & $56.2 \pm 1.0^{\mathrm{b}}$ & 31.25 & 125 & $41.9 \pm 2.1^{\mathrm{b}}$ & 15.625 & 500 \\
\hline
\end{tabular}

\%inhibition was done at $1000 \mu \mathrm{g} / \mathrm{mL}$ and represented by mean $\pm \mathrm{SD}(\mathrm{n}=3)$. MIC and MBC units are $\mu \mathrm{g} / \mathrm{mL}$. Different letters in \%inhibition column shows significant difference $(P<0.05)$ 


\section{ANTI-TYROSINASE ACTIVITY}

The anti-tyrosinase activities of all the extracts are presented in Table 5 as a percentage of inhibition at the concentration of $1000 \mu \mathrm{g} / \mathrm{mL}$ together with the $\mathrm{IC}_{50}$ values. The results showed that four plant extracts harbored anti-tyrosinase activity. Only the extracts from E. phaseoloides and P. cablin had inhibition of more than $50 \%$ compared to the negative control (all the reagents without the extract), with $\mathrm{IC}_{50}$ values of $543.83 \pm 51.06$ and $944.40 \pm 58.94 \mu \mathrm{g} / \mathrm{mL}$, respectively.

This is the first study on the tyrosinase inhibition activity of E. phaseoloides and elaborated on a possible function of this species for application in phytopharmaceuticals. Information regarding the isolation of compounds from the leaves of this plant is minimal. A previous study reported entadamide A from a 75\% ethanol extract of E. phaseoloides (Ikegami et al. 1989).
Entadamide A showed potential anti melanin inhibition with activity similar to arbutin, a common cosmetic ingredient (Sugimoto et al. 2018). Therefore, entadamide A could be responsible for inhibiting tyrosinase as a solute in the ethanol solvent.

P. cablin has displayed good activity of antityrosinase. This plant is widely used in the fragrance industry because of its essential oil (patchouli oil) with patchouli alcohol as the major constituent (Bunrathep et al. 2006). Patchouli alcohol is more abundant in the leaf than in the root or stem and it has been reported to possess a variety of biological activities, including antioxidative, antibacterial, and whitening properties (Hu et al. 2017). The whitening property of leaf extract and patchouli alcohol reduced melanin contents and intracellular tyrosinase activity in a dose-dependent manner in B16 melanoma cells (Bae et al. 2009).

TABLE 5. Anti-tyrosinase activities of ethanol extracts

\begin{tabular}{lcc}
\hline \multicolumn{1}{c}{ Sample } & \%inhibition & $\mathrm{IC}_{50}(\mu \mathrm{g} / \mathrm{mL})$ \\
\hline Kojic acid & $99.96 \pm 0.32^{\mathrm{a}}$ & $1.18 \pm 0.02^{\mathrm{a}}$ \\
B. macrocarpa & $13.00 \pm 1.20^{\mathrm{e}}$ & $>1000$ \\
E. phaseoloides & $76.44 \pm 0.96^{\mathrm{b}}$ & $543.83 \pm 51.06^{\mathrm{b}}$ \\
G. macrophyllus & $\mathrm{ND}$ & $>1000$ \\
G. crepidioides & $\mathrm{ND}$ & $>1000$ \\
H. robusta & $\mathrm{ND}$ & $\mathrm{ND}$ \\
L. elliptica & $45.93 \pm 4.03^{\mathrm{d}}$ & $>1000$ \\
P. cablin & $68.63 \pm 1.03^{\mathrm{c}}$ & $944.40 \pm 58.94^{\mathrm{c}}$ \\
R. tomentosa & $\mathrm{ND}$ & $\mathrm{ND}$ \\
\hline
\end{tabular}

ND: not detectable the anti-tyrosinase activity. \%inhibition was done at $1000 \mu \mathrm{g} / \mathrm{mL}$. All results were mean $\pm \operatorname{SD}(n=3)$ and followed by different letters to show statistically significant differences $(P<0.05)$

\section{ANTICANCER ACTIVITY}

The plant extracts were tested on MDA-MB-231 breast cancer cells for their cytotoxic effect. The $\mathrm{IC}_{50}$ values ranged from 49.74 to $877.71 \mu \mathrm{g} / \mathrm{mL}$ after $24 \mathrm{~h}$ incubation, as presented in Figure 1. R. tomentosa extract showed anticancer activity with an $\mathrm{IC}_{50}$ value below $50 \mu \mathrm{g} / \mathrm{mL}$. $P$. cablin and $H$. robusta also showed relatively high activity with $\mathrm{IC}_{50}$ values of 90.59 and $186.03 \mu \mathrm{g} / \mathrm{mL}$, respectively. 
Several compounds including naringenin and gallic acid had been isolated from ethanol $R$. tomentosa leaf extract (Liu et al. 2016). Naringenin was reported to inhibit MDA-MB-231 breast cancer cell growth by apoptosis induction and by suppressing caspase- 3 and -9 activities (Wang et al. 2018). Gallic acid, a common phenolic compound in plants, could also inhibit the growth of cancer cells, including MCF-7 and MDA-MB-231, without inhibiting that of normal cells (Subramanian et al. 2015). Tomentodione H-J and M, compounds from ethanol $R$. tomentosa leaves extract, showed strong effects when combined with doxorubicin to treat doxorubicin-resistant human breast cancer cells (MCF-7/ DOX) (Zhang et al. 2017).

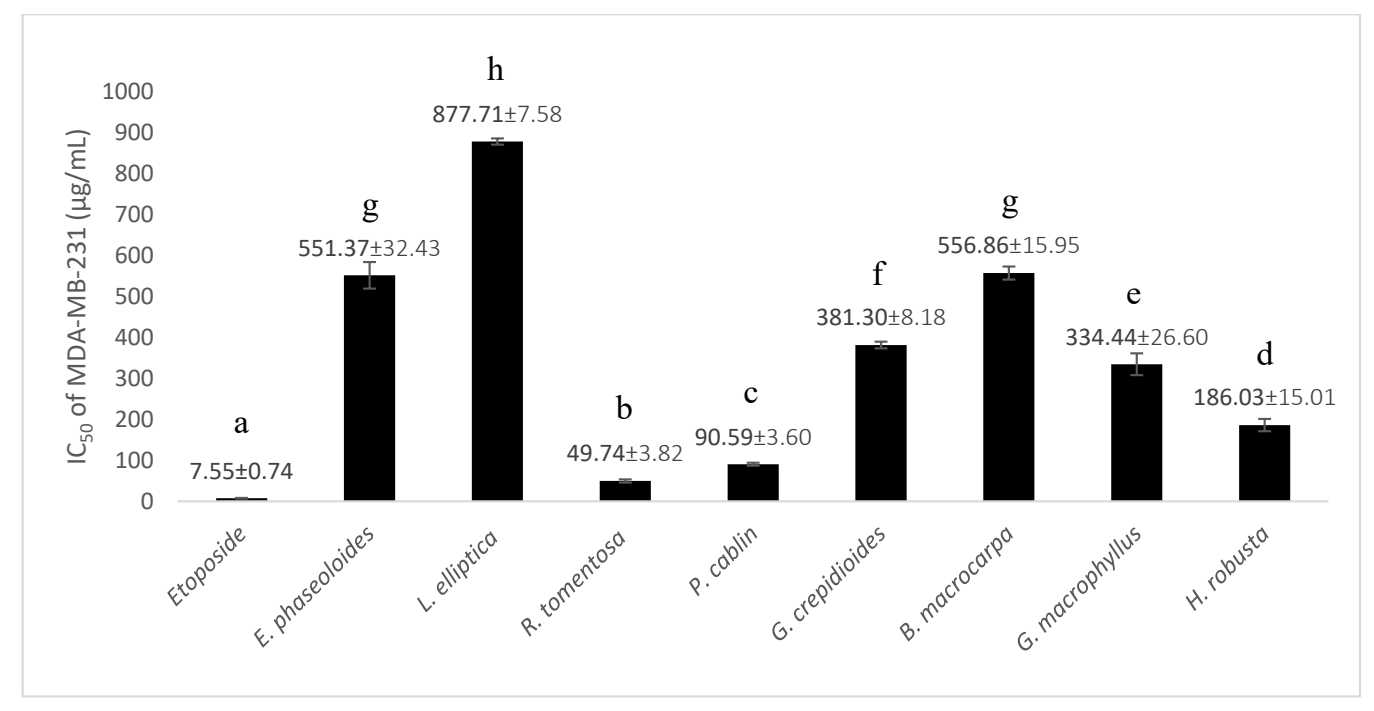

FIGURE 1. $\mathrm{IC}_{50}$ of MDA-MB-231 anticancer activity. All results are represented by mean $\pm \mathrm{SD}(\mathrm{n}=3)$. Statisticaly significant differences $(P<$ 0.05 ) are showed by differentiation of letters

\section{CONCLUSION}

This study demonstrated some activities of 8 medicinal plants used by the Dayak tribes in East Kalimantan, Indonesia. $H$. robusta ethanol extract possessed a high phenolic content and has potential as an antioxidant agent. $R$. tomentosa showed good antibacterial and anticancer activities. For anti-tyrosinase activity, our findings suggested E. phaseoloides as one of the candidates. New findings about the activities of these plant extracts could lead to the isolation and identification of active compounds for further pharmaceutical applications.

\section{ACKNOWLEDGEMENTS}

This study was financially supported by ASEAN scholarship, Chulalongkorn University and Kalimantan Timur Cemerlang Grant, Indonesia.

\section{REFERENCES}

Ahmmad, A., Islam, Md. T., Sultana, I., Mahmood, A., Hossain, J.A., Homa, Z., Ibrahim, M. \& Chowdhury, M.M.U. 2012. Pharmacological and phytochemical screening of ethanol extract of Litsea monopetala (Roxb.) Pers. IOSR Journal of Pharmacy 2(3): 398-402. 
Bae, S.Y., Lee, E.J., Son, R.H. \& Lee, Y.H. 2009. The inhibitory effects of Pogostemon cablin Bentham extract on melanogenesis. Journal of the Society of Cosmetic Scientists of Korea 35(1): 33-39.

Banerjee, M., Chattopadhyay, S., Choudhuri, T., Bera, R., Kumar, S., Chakraborty, B. \& Mukherjee, S.K. 2016. Cytotoxicity and cell cycle arrest induced by andrographolide lead to programmed cell death of MDAMB-231 breast cancer cell line. Journal of Biomedical Science 23(1): 1-16.

Benmehdi, H., Behilil, A., Memmou, F. \& Amrouche, A. 2017. Free radical scavenging activity, kinetic behavior and phytochemical constituents of Aristolochia clematitis L. roots. Arabian Journal of Chemistry 10(1): S1402-S1408.

Beveridge, T.J. 1999. Minireview structures of gram-negative cell walls and their derived membrane vesicles. Journal of Bacteriology 181(16): 4725-4733.

Bunrathep, S., Lockwood, G.B., Songsak, T. \& Ruangrungsi, N. 2006. Chemical constituents from leaves and cell cultures of Pogostemon cablin and use of precursor feeding to improve patchouli alcohol level. ScienceAsia 32(3): 293-296.

Chang, T. 2009. An updated review of tyrosinase inhibitors. International Journal of Molecular Sciences 10(6): 24402475.

Cheynier, V., Comte, G., Davies, K.M., Lattanzio, V. \& Martens, S. 2013. Plant phenolics: Recent advances on their biosynthesis, genetics, and ecophysiology. Plant Physiology and Biochemistry 72: 1-20.

Diba, F., Yusro, F., Mariani, Y. \& Ohtani, K. 2013. Inventory and biodiversity of medicinal plants from tropical rain forest based on traditional knowledge by ethnic Dayanese communities in West Kalimantan Indonesia. Kuroshio Science 7(1): 75-80.

Falleh, H., Jalleli, I., Ksouri, R., Boulaaba, M., Guyot, S., Magné, C. \& Abdelly, C. 2012. Effect of salt treatment on phenolic compounds and antioxidant activity of two Mesembryanthemum edule provenances. Plant Physiology and Biochemistry 52: 1-8.

Fu, R., Zhang, Y., Guo, Y. \& Chen, F. 2014. Antioxidant and tyrosinase inhibition activities of the ethanol-insoluble fraction of water extract of Sapium sebiferum (L.) Roxb. leaves. South African Journal of Botany 93: 98-104.

Golus, J., Sawicki, R., Widelski, J. \& Ginalska, G. 2016. The agar microdilution method - a new method for antimicrobial susceptibility testing for essential oils and plant extracts. Journal of Applied Microbiology 121: 1291-1299.

Hood, J.R., Wilkinson, J.M. \& Cavanagh, M.A. 2003. Evaluation of common antibacterial screening methods utilized in essential oil research. Journal of Essential Oil Research 15: 428-433.

Hu, G., Peng, C., Xie, X., Zhang, S. \& Cao, X. 2017. Availability, pharmaceutics, security, pharmacokinetics, and pharmacological activities of patchouli alcohol. Evidencebased Complementary and Alternative Medicine 2017: 4850612.

Ikegami, F., Sekine, T., Duangteraprecha, S., Matsushita, N., Matsuda, N., Ruangrungsi, N. \& Murakoshi, I. 1989. Entadamide C, a sulphur-containing amide from Entada phaseoloides. Phytochemistry 28(3): 881-882.

Jdey, A., Falleh, H., Jannet, S.B., Hammi, K.M., Dauvergne X., Ksouri, R. \& Magne, C. 2017. Phytochemical investigation and antioxidant, antibacterial and antityrosinase performance of six medicinal halophytes. South African Journal of Botany 112: 508-514.

Krishnaiah, D., Sarbatly, R. \& Nithyanandam, R. 2011. A review of the antioxidant potential of medicinal plant species. Food and Bioproducts Processing 89(3): 217-233.

Krisyanella, Dachriyanus \& Marlina. 2011. Characterization of simplicia and extract also isolation of antibacterial active compounds from Karamunting leaf (Rhodomyrtus tomentosa (W.Ait) Hassk). Journal of Faculty of Pharmachy, Andalas University: 1-17.

Kusuma, I.W., Ainiyati, N. \& Suwinarti, W. 2016. Search for biological activities from an invasive shrub species rose myrtle (Rhodomyrtus tomentosa). Nusantara Bioscience 8(1): 55-59.

Lallawmawma, H. 2016. Antioxidant potential of few selected medicinal plants of mizoram and their anti-ulcer activity in induced albino rats. $\mathrm{PhD}$ thesis. Mizoram University (Unpublished).

Limsuwan, S., Subhadhirasakul, S. \& Voravuthikunchai, S.P. 2009. Medicinal plants with significant activity against important pathogenic bacteria. Pharmaceutical Biology 47(8): 683-689.

Lin, F.J., Yen, F.L., Chen, P.C., Wang, M.C., Lin, C.N., Lee, C.W. \& Ko, H.H. 2014. HPLC-fingerprints and antioxidant constituents of Phyla nodiflora. The Scientific World Journal 2014: 528653.

Liu, H.X., Tan, H.B. \& Qiu, S.X. 2016. Antimicrobial acylphloroglucinols from the leaves of Rhodomyrtus tomentosa. Journal of Asian Natural Products Research 18(6): 1477-2213.

Mapunya, M.B., Nikolova, R.V. \& Lall, N. 2012. Melanogenesis and antityrosinase activity of selected South African plants. Evidence-Based Complementary and Alternative Medicine 2012: 374017.

Matius, P., Tjwa, S.J.M., Raharja, M., Sapruddin, Noor, S. \& Ruslim, Y. 2018. Plant diversity in traditional fruit gardens (munaans) of Benuaq and Tunjung Dayaks tribes of West Kutai, East Kalimantan, Indonesia. Biodiversitas 19(4): 1280-1288.

Muddathir, A.M., Yamauchi, K., Batubara, I., Mohieldin, E.A.M. \& Mistsunaga, T. 2017. Anti-tyrosinase, total phenolic content and antioxidant activity of selected Sudanese medicinal plants. South African Journal of Botany 109: 9-15. 
Mukaka, M.M. 2012. Statistics corner: A guide to appropriate use of correlation coefficient in medical research. Malawi Medical Journal 24(3): 69-71.

Patil, S., Srinivas, S. \& Jadhav, J. 2014. Evaluation of crocin and curcumin affinity on mushroom tyrosinase using surface plasmon resonance. International Journal of Biological Macromolecules 65: 163-166.

Pientaweeratch, S., Panapisal, V. \& Tansirikongkol, A. 2016. Antioxidant, anti-collagenase and anti-elastase activities of Phyllanthus emblica, Manilkara zapota and silymarin: An in vitro comparative study for anti-aging applications. Pharmaceutical Biology 54(9): 1865-1872.

Pillai, S., Oresajo, C. \& Hayward, J. 2005. Ultraviolet radiation and skin aging: Roles of reactive oxygen species, inflammation and protease activation, and strategies for prevention of inflammation-induced matrix degradation - A review. International Journal of Cosmetic Science 27(1): 17-34.

Pradeepa, K., Khrishna, V., Venkatesh, Kumar, K.G., Thirumalesh, B.V. \& Kumar, K.J.N. 2011. Antibacterial screening of the stem bark and leaf extracts of Litsea glutinosa (Lour.) C.B.Rob - An ethnomedicinally important tree of the Western Ghats. Pharmacognosy Journal 3(21): 72-76.

Prieto, P., Pineda, M. \& Aguilar, M. 1999. Spectrophotometric quantitation of antioxidant capacity through the formation of a phosphomolybdenum complex: Specific application to the determination of vitamin E. Analytical Biochemistry 269(2): 337-341.

Runtunuwu, A.E. 2013. Ethnoecological study of the utilization of medicinal plants by the dayak tunjung linggang tribe in West Kutai District, East Kalimantan province (in Indonesian). Bachelor Thesis. Universitas Sanata Dharma (Unpublished).

Saising, J., Ongsakul, M. \& Voravuthikunchai, S.P. 2011. Rhodomyrtus tomentosa (Aiton) Hassk. ethanol extract and rhodomyrtone: A potential strategy for the treatment of biofilm-forming staphylococci. Journal of Medical Microbiology 60(Pt 12): 1793-1800.

Sarker, S.D., Nahar, L. \& Kumarasamy, Y. 2007. Microtitre plate-based antibacterial assay incorporating resazurin as an indicator of cell growth, and its application in the in vitro antibacterial screening of phytochemicals. Methods 42(4): 321-324.

Sebaihi-Harzoun, S., Atmani-Kilani, D., Debbache-Benaida, N., Nana, F, Evain-Bana, E., Kirsch, G., Tabart, J., Kevers, C. \& Atmani, D. 2018. Phytochemical composition, antioxidant anti-proliferative properties of Genista ferox Poirret. aerial parts. European Journal of Integrative Medicine 23: 6-13.

Subramanian, A.P., John, A.A., Vellayappan, M.V., Balaji, A., Jaganathan, S.K., Supriyanto, E. \& Yusof, M. 2015. Gallic acid: Prospects and molecular mechanisms of its anticancer activity. Royal Society of Chemistry 5(45): 35608-35621.

Sugimoto, S., Matsunami, K. \& Otsuka, H. 2018. Biological activity of Entada phaseoloides and Entada rheedei. Journal of Natural Medicines 72(1): 12-19.
Wang, R., Wang, J., Dong, T., Shen, J., Gao, X. \& Zhou, J. 2018. Naringenin has a chemoprotective effect in MDAMB-231 breast cancer cells via inhibition of caspase-3 and -9 activities. Oncology Letters 17(1): 1217-1222.

Wilson, D.W., Nash, P., Buttar, H.S., Griffiths, K., Singh, R., De Meester, F., Horiuchi, R. \& Takahashi, T. 2017. The role of food antioxidants, benefits of functional foods, and influence of feeding habits on the health of the older person: An overview. Antioxidants 6(81): 1-20.

Wu, Y., Bai, J., Zhong, K., Huang, Y., Qi, H., Jiang, Y. \& Gao, H. 2016. Antibacterial activity and membrane-disruptive mechanism of 3-p-trans-coumaroyl-2-hydroxyquinic acid, a novel phenolic compound from pine needles of Cedrus deodara, against Staphylococcus aureus. Molecules 21(8): $1-12$.

Yadav, S., Trivedi, N.A. \& Bhatt, J.D. 2015. Antimicrobial activity of fresh garlic juice: An in vitro study. Ayu 36(2): 203-207.

Yamaguchi, Y., Takahashi, K., Zmudzka, B.Z., Kornhauser, A., Miller, S.A., Tadokoro, T., Barens, W., Beer, J.Z. \& Hearing, V.J. 2006. Human skin responses to UV radiation: Pigment in the upper epidermis protects against DNA damage in the lower epidermis and facilitates apoptosis. FASEB Journal 20(9): 1486-1488.

Yusro, F., Mariani, Y., Diba, F. \& Ohtani, K. 2014. Inventory of medicinal plants for fever used by four Dayak sub ethnic in West Kalimantan, Indonesia. Kuroshio Science 8(1): 33-38.

Zhang, Y.L., Zhou, X.W., Wu, L., Wang, X.B., Yang, M.H., Luo, J., Luo, J.G. \& Kong, L.Y. 2017. Isolation, structure elucidation, and absolute configuration of syncarpic acidconjugated terpenoids from Rhodomyrtus tomentosa. Journal of Natural Products 80(4): 989-998.

Zoremsiami, J. 2017. Investigation of the anticancer potential of Pasaltakaza, Helicia nilagirica Bedd. PhD Thesis. Mizoram University (Unpublished).

\section{Franxisca Mariani}

Biological Sciences Program

Faculty of Science

Chulalongkorn University

Bangkok 10330

Thailand

Franxisca Mariani, Hunsa Punnapayak \& Sehanat Prasongsuk* Plant Biomass Utilization Research Unit

Department of Botany, Faculty of Science

Chulalongkorn University

Bangkok 10330

Thailand

Franxisca Mariani \& Rachaneekorn Tammachote

Divison of Genetics

Department of Botany, Faculty of Science

Chulalongkorn University

Bangkok 10330

Thailand 
Irawan Wijaya Kusuma

Forest Products Chemistry Laboratory

Faculty of Forestry

Mulawarman University

Samarinda 75119

Indonesia

Warinthorn Chavasiri

Natural Products Research Unit

Department of Chemistry, Faculty of Science

Chulalongkorn University

Bangkok 10330

Thailand
Hunsa Punnapayak

Department of Biology

Faculty of Science and Technology

Universitas Airlangga

Surabaya 60115

Indonesia

*Corresponding author; email: sehanat.p@chula.ac.th

Received: 7 May 2020

Accepted: 31 December 2020 
SUPPLEMENTARY DATA 1. Antibacterial activities (zone of inhibition) of ethanol extracts

\begin{tabular}{|c|c|c|c|c|c|c|}
\hline Sample & $\begin{array}{l}\text { P. aeruginosa } \\
\text { TISTR } 1287\end{array}$ & $\begin{array}{c}\text { S. typhi } \\
\text { ATCC } 422\end{array}$ & $\begin{array}{c}\text { P. acnes } \\
\text { KCCM } 41747\end{array}$ & $\begin{array}{c}\text { S. aureus } \\
\text { ATCC } 25923\end{array}$ & $\begin{array}{c}\text { S. mutans } \\
\text { ATCC } 25175\end{array}$ & $\begin{array}{c}\text { S. sobrinus KCCM } \\
11898\end{array}$ \\
\hline Chloramphenicol & $13.67 \pm 0.94$ & $23.17 \pm 0.24$ & $30.33 \pm 0.47$ & $29.33 \pm 0.94$ & $18.89 \pm 0.38$ & $23.33 \pm 0.51$ \\
\hline B. macrocarpa & $10.10 \pm 0.71$ & $8.94 \pm 0$ & $8.80 \pm 0.24$ & $8.24 \pm 0$ & $8.90 \pm 0.19$ & $8.19 \pm 0.47$ \\
\hline E. phaseoloides & $8.20 \pm 0.24$ & $9.50 \pm 0.33$ & $7.31 \pm 1.89$ & $9.21 \pm 0$ & $8.29 \pm 0$ & $9.24 \pm 0.24$ \\
\hline G. macrophyllus & $8.84 \pm 0.24$ & $9.38 \pm 0.24$ & $8.46 \pm 0.47$ & $9.03 \pm 0.51$ & $7.44 \pm 0.51$ & $6.93 \pm 0.51$ \\
\hline G. crepidioides & $7.90 \pm 0.47$ & $8.76 \pm 0.71$ & $10.28 \pm 0.24$ & $8.36 \pm 0$ & $7.99 \pm 0.33$ & $8.05 \pm 0.19$ \\
\hline H. robusta & $7.85 \pm 0.51$ & $8.60 \pm 0.19$ & $8.67 \pm 0.24$ & $8.71 \pm 0.24$ & $7.90 \pm 0.24$ & $7.84 \pm 0.19$ \\
\hline L. elliptica & $6.67 \pm 0.47$ & $9.73 \pm 0.24$ & $9.89 \pm 0.33$ & $9.62 \pm 0.24$ & $10.45 \pm 0.24$ & $9.10 \pm 0.47$ \\
\hline P. cablin & $7.53 \pm 0.19$ & $8.34 \pm 0.47$ & $8.58 \pm 0.33$ & $7.68 \pm 0.51$ & $7.95 \pm 0.33$ & $7.35 \pm 0.33$ \\
\hline R. tomentosa & $7.35 \pm 0$ & $8.67 \pm 0.47$ & $9.46 \pm 0$ & $9.39 \pm 0$ & $10.62 \pm 0$ & $9.78 \pm 0.33$ \\
\hline
\end{tabular}

Zone of inhibition was done at $1000 \mu \mathrm{g} / \mathrm{mL}$ and represented by mean $\pm \mathrm{SD}(\mathrm{n}=3)$ in $\mathrm{mm}$ 